\title{
PERAN TERAPI KELUARGA EKSPERIENSIAL DALAM KONSELING ANAK UNTUK MENGELOLA EMOSI
}

\author{
Widayat Mintarsih \\ Fakultas Dakwah dan Komunikasi \\ IAIN Walisongo Semarang
}

\begin{abstract}
Abstrak
Keberhasilan proses konseling anak sangat membutuhkan peran dari anggota keluarga. Keluarga merupakan tempat yang pertama bagi anak untuk mendapatkan pendidikan bagaimana mengelola emosi dengan baik. Tujuannya adalah agar anak dapat melaksanakan tugas perkembangan secara optimal sesuai dengan potensi yang dimilikinya. Salah satu upaya yang dapat dilakukan oleh keluarga untuk mengatasi jika terjadi masalah pada anak adalah dengan melakukan konseling anak berbasis terapi keluarga eksperiensial dengan melibatkan seluruh anggota keluarga.

Terapi keluarga eksperiensial menekankan pada proses pertumbuhan alamiah dalam keluarga untuk meningkatkan rasa memiliki keluarga dan memberikan kebebasan sebagai individu dalam keluarga agar memiliki pengalaman dalam mengekspresikan emosi. Terapi eksperiensial bersifat eksistensial, humanistik, dan fenomenologis. Tujuan terapi ini adalah membantu memperjelas komunikasi dalam keluarga, menghindarkan adanya keluhan-keluhan, sehingga ada usaha untuk menemukan solusi. Untuk itu seluruh anggota keluarga ikut aktif terlibat dalam proses konseling dan tetap mempertahankan harga diri yang positif.

Konseling anak dengan terapi keluarga eksperiensial diharapkan mampu melahirkan efek fungsi terapis dan dinamika psikologis bagi anak dalam berperilaku yang positif, sesuai dengan peran dalam memenuhi kebutuhan emosionalnya. Cara yang dilakukan anak untuk memenuhi kebutuhan emosionalnya berdasarkan cara pandang yang terbaik menurut yang mereka ketahui. Hal itu merupakan tantangan bagi orang tua dan anggota keluarga bagaimana menghadapi dan mengelola perkembangan emosional secara positif yang terjadi pada anak.
\end{abstract}

Kata Kunci: konseling anak, terapi keluarga eksperiensial, mengelola emosi 


\section{A. Pendahuluan}

Keluarga memiliki peran yang sangat penting dalam memberikan pendidikan pada anak, apalagi perkembangan anak yang begitu cepat pada usia sekolah. Lingkungan keluarga yang sempit tidak cukup untuk memberikan fasilitas kepada anak dalam menghadapi perkembangan sosialnya dan dibutuhkan lingkungan di luar keluarga yaitu sekolah. Di lingkungan sekolah anak akan mengembangkan diri sebagai individu dan sebagai makhluk sosial sesuai dengan potensi yang dimilikinya.

Di sekolah anak akan belajar memahami peraturan, cara belajar dengan teman, mentaati perintah guru, dan berbagai macam kegiatan yang melatih kemampuan perkembangan motorik dan emosinya. Anak akan mendapat pengalaman dalam memperluas cakrawala di luar lingkungan keluarga melalui kegiatan di sekolah secara objektif. Hal ini mampu melatih anak untuk merangsang timbulnya kesadaran akan kewajiban dan tanggung jawabnya sebagai siswa.

Melaksanakan kewajiban dan tanggung jawab menjadi siswa tidak mudah bagi anak karena kebiasaan di lingkungan keluarga yang sempit menjadi lingkungan sekolah yang lebih luas. Kondisi lingkungan sekolah yang berbeda dengan kondisi keluarga akan memberikan pelajaran yang sangat berharga pada anak sehingga mampu bersosialisasi, menyesuaikan diri, dan mengelola emosi. Banyak ketrampilan yang bisa dikuasai, aktivitas dan kebiasaan-kebiasaan tertentu mulai dikembangkan sehingga sifat kritis mulai muncul pada diri anak.

Perkembangan sifat kritis dan intelektual pada masa ini sangat pesat, segala sesuatu yang aktif dan bergerak akan sangat menarik minat perhatian anak. Orang tua harus memahami bahwa masa akhir kanak-kanak oleh para pendidik memandang sebagai periode kritis dalam dorongan berprestasi. Tingkat perilaku berprestasi pada masa kanak-kanak mempunyai korelasi yang tinggi dengan perilaku berprestasi pada masa dewasa. ${ }^{1} \mathrm{Jika}$ pada periode kritis anak tidak mendapat dukungan dari orang tua maka anak akan merasa kecewa, bahkan bisa meledakkan amarahnya.

\footnotetext{
${ }^{1}$ Elizabeth B. Hurlock, Psikologi Perkembangan, (Jakarta: Erlangga, 2004), hlm. 146.
} 
Ada situasi yang bisa mengungkapkan emosi anak dan ada pula situasi yang bisa membangkitkan emosi. Anak akan mudah marah jika selalu direndahkan dan membangkitkan emosi jika anak ingin tahu sesuatu yang menarik. Meningginya emosi bisa disebabkan karena suasana kurang menyenangkan dan ketidakseimbangan antara harapan dan kenyataan sehingga anak sulit untuk menghadapi. Selain itu juga bisa disebabkan karena keadaan fisik dan lingkungan. Jika anak lelah atau sakit, anak cenderung cepat marah dan sulit dihadapi. Kondisi lingkungan yang kurang mendukung menyebabkan meningginya emosi pada anak dalam melakukan hubungan interpersonal. Lingkungan baru juga bisa menyulitkan anak dalam menyesuaikan diri.

Kondisi meningginya emosi pada anak akan semakin buruk, jika tidak ada kenyamanan dalam lingkungan keluarga. Hal itu akan mengganggu anak dalam melaksanakan tugas perkembangannya. Jika anak mengalami gangguan untuk melaksanakan tugas perkembangannya bisa diberi bantuan melalui proses konseling. Proses konseling anak sangat membutuhkan peran terapi keluarga. Untuk itu peran terapi keluarga sangat berpengaruh dalam membantu menurunkan emosi pada diri anak, sehingga anak mampu menyesuaikan diri dan mengembangkan potensi yang ada pada dirinya secara optimal.

\section{B. Konseling Anak}

Proses konseling bisa dilakukan mulai dari anak-anak, remaja, dewasa dini, sampai dewasa lanjut. Memberikan konseling pada anak tidak bisa disamakan seperti memberikan konseling pada orang dewasa. Orang dewasa mudah untuk diajak duduk bersama membicarakan permasalahan yang menimpanya. Sedangkan anak akan cepat bosan jika disuruh berdiam diri beberapa saat untuk menjawab pertanyaan konselor. Bisa juga terjadi suasana menghindari untuk mengemukakan penyebab masalah yang timbul pada dirinya.

Konselor pada saat melakukan proses konseling pada anak harus mampu melibatkan diri berkomunikasi verbal maupun non verbal dengan anak-anak. Selain itu juga memahami sifat, tujuan, penggunaan media dan 
ide kreatif dalam memberikan konseling pada anak agar tujuan tercapai. Pencapaian tujuan tidak hanya bergantung pada konselor tapi juga membutuhkan peran keluarga dalam proses konseling. Konselor harus memahami apa tujuan orangtua untuk memberikan konseling pada anak, sehingga tujuan konseling bisa terfokuskan dalam proses terapi.

Menurut David dan Kathryn Geldard tujuan proses konseling pada anak memiliki empat tingkatan, yaitu: ${ }^{2}$

1. Tujuan tingkat 1 adalah tujuan fundamental.

2. Tujuan tingkat 2 adalah tujuan orangtua.

3. Tujuan tingkat 3 adalah tujuan yang dirancang oleh konselor.

4. Tujuan tingkat 4 adalah tujuan anak-anak.

Tujuan fundamental bisa diterapkan secara global bagi semua anakanak dalam terapi, yaitu memberdayakan anak-anak untuk menghadapi masalah emosional yang menyakitkan, mencapai tingkatan kongruen yang berkaitan dengan pemikiran, emosi, dan perilaku, merasa nyaman dengan dirinya, menerima keterbatasan dan kelebihan dirinya, mampu merubah sikap yang berdampak negatif, bisa berfungsi dan beradaptasi dengan lingkungan rumah maupun di sekolah, serta memaksimalkan peluang bagi anak untuk mewujudkan target pencapaian.

Tujuan orangtua ketika melakukan proses konseling biasanya didasarkan pada perilaku terakhir anak. Misalnya jika anak suka melawan pembicaraan orangtua, maka tujuannya adalah bagaimana anak mampu menjadi pendengar yang baik.

Tujuan yang dirancang konselor adalah sebagai konsekuensi hipotesis yang dimiliki konselor mengenai alasan seorang anak memiliki sikap tertentu. Misalnya tidak mampu menjadi pendengar yang baik merupakan akibat dari perubahan atau keadaan kurang mampu mengelola emosi. Sehingga konselor memiliki tujuan untuk mengatasi dan menaggulangi sisi kemampuan pengelolaan emosional pada anak.

2 David dan Kathryn Geldard, Konseling Anak-anak, (Yogyakarta: Pustaka Pelajar, 2011), hlm. 5-7. 
Keinginan anak-anak akan muncul selama proses konseling. Konselor akan mengetahui apa sebenarnya yang diinginkan oleh anak, meskipun kadangkala anak tidak mampu menyampaikan secara verbal. Tujuan ini kadangkala bisa dilihat dari benda-benda yang dibawa oleh anak selama proses konseling. Agar kebutuhan anak-anak yang sebenarnya muncul dan bisa terpenuhi, konselor harus patuh dengan proses yang diinginkan oleh anak. Paling tidak mampu membuat anak merasa nyaman, sehingga konselor membuat sesi yang bisa memenuhi kebutuhan anak.

Menciptakan hubungan pada awal proses konseling memiliki pengaruh yang sangat besar terhadap keberlanjutan proses berikutnya. Sebagai konselor harus memahami dan mampu menciptakan hubungan baik dengan anak-anak, memahami persepsinya, serta mampu mengobservasi hal-hal yang dialami oleh anak-anak. Anak akan memiliki persepsi pribadi yang tidak sama dengan persepsi orangtua. Agar hubungan dalam proses konseling efektif, anak harus merasa diterima oleh konselor dengan cara yang sama dengan anak, bagaimana ia juga menerima dirinya. Hal itu bisa dilakukan dengan selalu menjaga hubungan agar tetap eksklusif dan tidak membiarkan pihak lain turut campur tangan tanpa seizin anak. Anak harus diupayakan selalu aman dan nyaman serta tidak dibuat-buat dalam melakukan interaksi.

Selain mampu menciptakan hubungan baik dengan si anak seorang konselor harus mampu berhubungan dengan sisi kekanakannya. Menemukan sisi anak-anak tidak berarti menjadi kekanak-kanakan, tetapi berhubungan dengan bagian diri kita yang sesuai dengan dunia anak-anak. Jika konselor mampu menghidupkan sisi kekanakan dan memasukinya, maka akan mudah bergabung dengan anak-anak serta memahami perasaan mereka sehingga bisa meminimalisir perasaan yang mengganggu atau ketidakseimbangan emosi pada diri anak.

Anak biasanya menghindari emosi yang tidak menyenangkan, dan cenderung untuk menekan perasaan itu. Jika konselor ingin mendorong anak-anak menggali sisi pribadi yang tidak sehat pada diri anak, maka harus mampu bersikap dengan cara yang paling bisa diterima anak sehingga anak merasa diizinkan untuk menjadi diri mereka sendiri tanpa batasan. Dalam 
bersikap menerima konselor tidak menunjukkan penerimaan atau penolakan, tetapi menerima dengan sikap yang tidak menghakimi pada siapapun dan terhadap apa yang sudah dilakukan oleh anak.

Selain mampu menciptakan hubungan baik, agar proses konseling bisa maksimal serta efektif, konselor harus memiliki banyak informasi mengenai permasalahan dan perilaku anak, juga sikap emosionalnya. Latar belakang budaya dan lingkungan tempat tinggal anak juga harus benar-benar dipahami konselor. Informasi tersebut bisa didapatkan dari orangtua, saudara, personil sekolah, teman dekat, praktisi kesehatan, lembaga pemerintah, dan sumber lainnya. Informasi yang ada kaitannya dengan masalah anak sangat bermanfaat untuk membantu konselor memahami anak.

\section{Perlunya Memilih Media yang Sesuai untuk Proses Konseling}

Pada awal proses kegiatan konseling, konselor harus memutuskan media yang paling sesuai dan akan digunakan dalam proses konseling. Pemilihan ini bisa berdasarkan pada usia, gender, kepribadian, dan jenis masalah emosional. Media digunakan sebagai cara untuk melibatkan anakanak dan membuat mereka mampu bercerita mengenai kisah dan permasalahnnya. Sebelum memilih media konselor harus memahami dan mendapatkan informasi tentang permasalahan anak, karena setiap anak memiliki perbedaan latar belakang budaya keluarga walaupun jenis permasalahannya sama. Faktor-faktor penting ketika memilih media atau aktivitas untuk konseling anak adalah: (1) Tahapan perkembangan usia anak. (2) Apakah anak-anak diberi konseling secara individual atau kelompok? (3) Tujuan konseling bagi anak-anak ${ }^{3}$

Jika melihat tahapan perkembangan disesuaikan dengan usia anak, misalnya usia prasekolah usia 2-5 tahun, media atau aktivitas yang sesuai yaitu: buku cerita, tanah liat, konstruksi, gambar, melukis dengan jari, permainan games, permainan imajinatif, lukisan, boneka/mainan, bak pasir, simbol/patung. Sedangkan anak usia Sekolah Dasar 6-10 tahun media atau aktivitas yang sesuai yaitu: buku cerita, tanah liat, konstruksi,

\footnotetext{
${ }^{3}$ Ibid., hlm. 276-277.
} 
gambar, melukis dengan jari, permainan games, perjalanan/permainan imajinatif, hewan miniatur, lukisan, boneka/mainan, bak pasir, simbol/ patung, kertas kerja.

Konselor dalam memilih media bisa bekerja secara individual atau bekerjasama dengan kelompok saudara atau kelompok anak-anak yang memiliki permasalahan yang serupa, atau dilaksanakan dalam lingkup keluarga. Adapun penggunaan contoh media yang bisa mendorong anak mengekspresikan emosinya secara efektif, misalnya: menggambar membuat anak-anak berhubungan tidak hanya dengan proyeksi pikiran, tetapi juga dengan perasaan emosional; mengecat cenderung menghasilkan emosi kesenangan, perayaan, dan kebahagiaan; melukis dan membuat kolase, anak dapat menghubungkan tekstur bahan dengan perasaan emosional. Diharapkan dengan menggunakan media atau kegiatan, proses konseling bisa kebih efektif dan fokus pada pengentasan masalah yang dialami oleh anak sesuai dengan potensi yang dimiliki.

\section{Terapi Keluarga Eksperiensial}

Keluarga tumbuh sebagai sebuah sistem yang merupakan fondasi dasar dalam terapi keluarga. Sistem keluarga terdiri dari sekelompok individu dan ketika semua individu tersebut saling berinteraksi akan membuahkan tanggapan dan pola perilaku, pada gilirannya akan mempengaruhi keluarga secara keseluruhan. ${ }^{4}$ Setiap individu sebagai anggota dalam keluarga akan memiliki persepsi yang berbeda-beda terhadap anggota keluarga lainnya dan akan mempengaruhi keyakinan dan sikap-sikapnya yang dikondisikan oleh sifat kepribadian individu itu sendiri.

Sifat kepribadian yang berbeda-beda akan cenderung memunculkan konflik dalam keluarga. Masing-masing anggota keluarga memiliki pemikiran dan perilakunya sendiri-sendiri sesuai dengan persepsinya. Mereka juga melakukan aktivitas yang dianggapnya paling baik untuk memenuhi kebutuhannya termasuk kebutuhan emosional dan fisiknya dalam mengurangi

${ }^{4}$ Geldard Kathryn dan G David, Konseling Keluarga, (Yogyakarta: Pustaka Pelajar. 2011), hlm. 97. 
kecemasan dan agar merasa aman. Kadangkala yang ditempuh oleh salah satu anggota keluarga bisa membuat tidak nyaman bahkan meresahkan anggota keluarga yang lain. Hal itu bisa memunculkan konflik antar anggota keluarga. Dalam situasi yang seperti itu jika tidak bisa diatasi oleh anggota keluarga, tentu saja membutuhkan bantuan seorang konselor.

Konselor dalam memberikan bantuan proses konseling dalam sebuah keluarga bisa menggunakan berbagai macam pendekatan. Banyak model konseling yang proses kegiatannya mengaitkan relasi antar anggota keluarga. Keluarga tumbuh sebagai sebuah sistem yang merupakan fondasi dasar dalam terapi keluarga. Salah satu diantaranya adalah menggunakan terapi keluarga eksperiensial. Pendekatan ini menekankan pada pentingnya mengalami dan mengekspresikan emosi here and now. Tipe terapi ini menekankan pada proses pertumbuhan alamiah dalam keluarga, membantu para anggota keluarga untuk meningkatkan rasa memiliki keluarga, juga meningkatkan kemampuan keluarga itu untuk memberikan kebebasan sebagai individu kepada setiap anggotanya. Tokoh yang memberikan banyak kontribusi dalam terapi keluarga eksperiensial adalah Carl Whittaker, Virginia Satir, August Napier, David Keith, dan Leslie Greenberg. Terapi keluarga eksperiensial bersifat eksistensial, humanistik dan fenomenologis. ${ }^{5}$

Kaum eksistensialis berpendapat bahwa dalam memahami eksistensi manusia bisa diperoleh melalui pengalaman-pengalaman pribadi. Pengalaman merupakan guru yang terbaik bagi individu. Oleh karena itu dalam proses konseling, konselor membantu klien memilih pengalaman pribadi mana yang mampu mempengaruhi mereka untuk berhubungan dengan emosi-emosi selama proses terapi.

Kaum humanis berpandangan bahwa dalam proses terapi membutuhkan keyakinan adanya kearifan alamiah, adanya komunikasi, dan emosi yang jujur. Secara alamiah manusia memiliki akal, jika diberi kebebasan untuk menggunakannya maka akan lebih bersemangat, kreatif, dan produktif.

\footnotetext{
${ }^{5}$ Ibid., hlm. 13.
} 
Pandangan kaum fenomenologi adalah dalam memahami individu dilihat dari lingkungan yang membentuknya. Jika lingkungan kurang baik, maka diupayakan mampu merubah lingkungan agar mampu membangun kepribadian individu ke arah yang lebih baik. Hal itu bisa digambarkan bahwa keluarga yang sehat akan memberikan keleluasaan individu untuk mengembangkan potensinya dan tidak mengabaikan kebersamaan. Setiap anggota keluarga cukup memiliki rasa aman untuk mengemukakan perasaan dan pendapatnya, sehingga mampu menjadi diri sendiri.

Terapi keluarga eksperiensial memusatkan perhatian pada subjektivitas individu. Semua anggota keluarga memiliki hak untuk menjadi diri sendiri, jangan sampai tuntutan keluarga bersifat menindas anggota keluarga. Selain itu juga membantu individu untuk mampu berkomunikasi melalui emosiemosinya secara jujur sehingga mampu mengungkapkan perasaan tanpa adanya tekanan dan paksaan.

Peran terapi adalah sebagai katalisator perubahan, dengan memanfaatkan dampak personal individu dalam keluarga. Misalnya dalam hal berbagi perasaan dengan keluarga. Hal ini bisa memunculkan transferensi (pemindahan) dan kontratransferensi. Untuk itu dibutuhkan usaha menyampaikan perasaan terbuka agar kontratransferensi bisa diminimalisir. Tujuan terapi ini juga membantu memperjelas komunikasi dalam keluarga dan menghindarkan adanya keluhan-keluhan, sehingga ada usaha untuk menemukan solusi. Untuk itu anggota keluarga ikut aktif terlibat dalam proses konseling dan tetap mempertahankan harga diri yang positif.

Untuk mencapai kesuksesan dalam mencapai tujuan konseling, konselor harus aktif terlibat dalam proses konseling. Selain itu juga dapat menggunakan beberapa teknik strategi ekspresif dari terapi Gestalt dan psikodrama. Konselor eksperiensial memusatkan perhatian pada pengalaman langsung pada saat ini dan sekarang, serta ungkapan perasaan klien. Tujuan penggunaan teknik ini adalah memberikan pengalaman kepada keluarga yang memungkinkan mereka bisa berkomunikasi menggunakan emosi-emosinya sekaligus meningkatkan fungsi kesadaran mereka terhadap perannya dalam anggota keluarga. 
Alternatif lain terapi eksperiensial memberi kesempatann eksperimentasi dengan menggunakan fungsi alternatif secara sederhana yaitu menggunakan patung keluarga. Pembuatan patung keluarga bisa meningkatkan kesadaran tiap anggota keluarga sesuai dengan peran, fungsi, dan relasi mereka dengan sesama anggota keluarga dan orang lain. Untuk membuat patung keluarga bisa dengan menggunakan bantal yang berwarna-warni, simbol-simbol, atau anggota keluarga secara langsung.

Patung keluarga bisa digunakan untuk mengatasi problem keluarga dalam situasi dan kondisi seperti misalnya: ada problem kekuasaan dan kerenggangan keintiman pada keluarga, bila para anggota merasa kesulitan untuk mengungkapkan pendapat mereka secara verbal, anggota keluarga terlalu mengunggulkan kecerdasan dan mengabaikan komponen emosional komunikasi mereka, adanya penolakan ungkapan perasaan anggota keluarga, keluarga kesulitan untuk memahami penggambaran verbal anggotanya. Dalam proses konseling terapi bisa menggunakan teknik eklektik, artinya menggabung beberapa teknik konseling yang disesuaikan dengan permasalahan yang dialami dalam keluarga serta keaktifan seluruh anggota keluarga sangat diharapkan oleh terapi.

\section{E. Perkembangan Emosi Anak}

Emosi merupakan warna afektif yang menyertai setiap perilaku individu, berupa perasaan-perasaan tertentu yang dialami pada saat menghadapi situasi tertentu. ${ }^{6}$ Emosi bisa timbul karena situasi tertentu, atau bisa juga terjadi dalam kaitannya dengan perilaku yang mengarah atau menyingkiri terhadap sesuatu, dan perilaku tersebut pada umumnya disertai adanya ekspresi kejasmanian, sehingga orang lain dapat mengetahui bahwa seseoranng sedang mengalami emosi.?

Reaksi emosi dapat secara akurat dan terkadang tidak akurat untuk diinterpretasikan apabila tidak memahami perkembangan individu, karena antara kognisi, emosi dan motorik merupakan suatu sistem yang berpengaruh secara timbal balik. Namun demikian kadang-kadang orang masih dapat

${ }^{6}$ Surya Muhamad, Psikologi Konseling, (Jakarta: Pustaka Bani Quraisy, 2003), hlm. 91.

${ }^{7}$ Bimo Walgito, Pengantar Psikologi Umum, (Yogyakarta: Andi Offset, 2004), hlm. 209. 
mengontrol keadaan emosi dirinya sehingga tidak sampai tercetus keluar dengan perubahan atau tanda jasmaniah lainnya. Walaupun individu itu sedih yang disebabkan karena kehilangan anggota keluarganya misalnya, tapi masih dapat meredam dan menyembunyikan dan tidak ada gejala jasmaniah yang muncul.

Pada masa awal kanak-kanak, umumnya emosi bisa berkembang dengan pesat. Proses perkembangannya bisa melalui proses belajar secara langsung maupun tidak langsung. Bisa dimulai dari perhatian, pengalaman, atau peristiwa baru yang dialami anak. Hal itu bisa ditandai oleh ledakan marah jika keinginannya tidak terpenuhi, ketakutann yang hebat, iri hati terhadap adik, teman, atau saudara kandungnya. Peristiwa lain yang menyebabkan kuatnya emosi anak disebabkan karena kelemahan dari faktor fisik akibat dari kelelahan bermain, tidak mau tidur siang, atau bisa karena sulit makan. Disamping itu anak juga tidak bisa menyalurkan kegiatan atau melakukan sesuatu sesuai dengan keinginannnya. Bisa juga karena pemaksaan kehendak orang tua agar anak melaksannakan sesuatu di luar kemampuan anak.

Pengungkapann emosi anak bisa dengan menangis, cemberut kalau sedih, tersenyum atau tertawa jika senang. Perkembangan emosi yang senang nantinya akan berkembang menjadi kasih sayang dan penuh harapan, sedangkan perasaan tidak senang akan berkembang menjadi kecewa, cemas, rendah diri, rasa malu, dansebagainya. Sebaliknya perkembangan emosi pada anak harus selalu diperhatikann oleh orangtua agar berkembang lebih sempurna dan halus sehingga tidak ada gangguan dalam perkembangan emosi. Perkembangan pola emosi umum yanng terjadi pada awal masa kanak-kanak antara lain: ${ }^{8}$

\section{Marah}

Penyebab emosi marah paling umum terjadi diakibatkan karena pertengkaran dengan teman, berebut mainan, tidak tercapainya keinginan dan mendapat serangan dari teman lain. Bentuk ungkapan marah yaitu: menangis, berteriak, menggertak, menendang, melompat, memukul.

${ }^{8}$ Rumini S dan Sundari S., Perkembangan Anak dan Remaja, (Jakarta: Rineka Cipta, 2004), hlm. 48-49. 


\section{Takut}

Anak takut dengan situasi kondisi dan lingkungan yang kurang bersahabat. Misalnya terhadap orang yang belum dikenal, takut akan kegelapann, binatang buas, melihat gambar, mendengar cerita, suara keras, melihat adegan di TV, dan sebagainya. Reaksi anak dalam mengekspresikan ketakutannya pada umumnya memunculkan kepanikan pada diri diri, kemudian menghindar, lari, bersembunyi,dan menangis.

\section{Cemburu}

Emosi cemburu bisa disebabkan karena anak merasa orang tua membagi kasih sayangnya kepada saudara, adik, atau orang lain. Ungkapan cemburu biasa dilakukan oleh anak-anak dengan berpura-pura sakit, melaksanakan kegiatan nyang mencari perhatian orang tua. Bisa juga perilakunya menjadi nakal, agresif, atau melakukan hal-hal yang dulu belum pernah dilakukan.

\section{Ingin Tahu}

Keinginan anak untuk mengetahui hal-hal baru di sekelilingnya sangat tinggi. Anak juga mulai ingin mengetahui kondisi tubuhnya sendiri. Reaksinya adalah anak banyak bertanya tentang segala sesuatu yang membuatnya tertarik untuk dipahami dan dimengerti.

\section{Iri Hati}

Iri hati yang dialami oleh anak banyak disebabkan karena menginginkan sesuatu yang dimiliki oleh orang lain atau temannya baik berupa barang, mainan, atau kemampuan mencari perhatian dan mendapatkan kasih sayang. Ungkapan iri hati bisa dengan mengeluh tentang hal-hal yang dimiliki, meminnta untuk dipenuhi keinginan memiliki barang tersebut atau mungkin bisa terjadi anak mengambil benda yang ingin dimilikinya.

\section{Gembira}

Dalam kondisi sehat anak akan merasa gembira. Lingkungan aman dan nyamann, serta layak untuk melakukan aktivitas kegiatan bermainnya. Perasaan gembira pada anak juga terjadi jika anak mampu menyelesaikan 
tugasnya yang dianggap sulit. Kegembiraan bisa diungkapkan dengan tersenyum, tertawa, bertepuk tangan, melompat-lompat, bercanda, memeluk orang tua, teman, benda, atau orang lain yang bisa membuat nanak bahagia.

\section{Sedih}

Kondisi anak sedih bisa diakibatkan karena kehilangan sesuatu yang disenangi atau bisa juga keinginannya tidak terpenuhi. Ungkapan sedih bisa dengan menangis, merenung, tidak bergairah dalam melakukan kegiatan rutinitas sehari-hari.

\section{Kasih Sayang}

Anak mendapat kasih sayang dari keluarga dan orang lain yang menyayanginya. Diharapkan anak belajar mencintai keluarga dan orang lin yang ada di sekitarnya. Ungkapan kasih sayang bisa dilakukan oleh anak dengan memeluk, mencium, menepuk, mengajak berbicara atau komunikasi yang baik, atau bisa juga mengelus-elus dan menggendong boneka atau bianatang kesayangannya.

\section{F. Peran Terapi Keluarga Eksperiensial dalam Proses Konseling Anak untuk Mengelola Emosi}

Proses konseling anak sangat membutuhkan peran dari anggota keluarga. Keluarga merupakan hubungan atau interaksi antara dua orang atau lebih dan mempunyai ikatan darah, ikatan karena perkawinan, kekerabatan yang didalamnya terdapat suatu sistem saling mengikat satu sama lain seperti adanya aturan-aturan, perbedaan budaya, dan perbedaan peran setiap anggota. ${ }^{9}$ Lingkungan keluarga merupakan suatu tempat dimana anak berinteraksi sosial dengan orang tua yang paling lama. Perkembangan sistem sosial dikembangkan dalam keluarga untuk memberikan pengalaman pada anak bagaimana menyesuaikan diri dengan lingkungan di luar keluarga.

${ }^{9}$ Kertamuda E Fatchiah, Konseling Pernikahan untuk Keluarga Indonesia, (Jakarta: Salemba Humanika, 2009), hlm. 47. 
Berbagai macam problematika bisa muncul dalam keluarga, apalagi masalah anak. Seringkali perilaku anak tidak sesuai dengan keinginan dan harapan orang tua. Orang tua merasa khawatir dengan sikap anaknya yang tidak sesuai dan suka mengganggunya karena dianggap perkembangan anak tidak sesuai dengan yang lainnya. Jika anak mendapat tekanan dan penolakan dari orang dewasa atau anggota keluarga lain, maka secara emosional akan terganggu dan akan memunculkan sifat buruk. Anak akan terganggu dalam melaksanakan hubungan interpersonal, dan bisa juga memunculkan perilaku yang bersifat maladaptif atau tidak diterima oleh lingkungan.

Perilaku anak yang tidak bisa diterima oleh lingkungan akan berdampak pada anggota keluarga lainnya. Apalagi jika perilaku tersebut disebabkan oleh gangguan emosional yang tidak terselesaikan dalam lingkungan keluarga. Hal itu akan berdampak buruk bagi perkembangan emosi anak selanjutnya. Untuk itu dibutuhkan interaksi yang intens dalam keluarga untuk menjaga agar emosi anak tidak terganggu. Jika keluarga tidak mampu mengatasi masalah anggota keluarga, maka dibutuhkan konselor untuk membantu menyelesaikan masalah yang menimpa keluarganya.

Konselor dalam melakukan proses konseling anak, bisa secara individu maupun kelompok. Ada anggapan bahwa bekerja dengan anak-anak sudah cukup membantu mengatasi masalah yang mengganggu. Ada pula yang melakukan tradisi terapi keluarga dan meyakini bahwa terapi keluarga saja sudah cukup. Beberapa ahli terapi keluarga mengatakan bahwa bekerja secara individual dengan anak tidak baik karena anak akan menjadi kambing hitam dan dianggap sebagai sumber masalah. Beberapa konselor yang bekerja dengan anak meyakini bahwa terapi keluarga tidak memberi kesempatan kepada anak untuk mengatasi masalah yang mengganggu secara pribadi dan bersifat sensitif. Hal itu perlu dipahami bahwa pada saat selesai proses konseling dengan anak, maka selanjutnya anak akan mampu membagi informasi pada keluarga. Jika terapi keluarga saja yang digunakan, informasi yang didapat hanya bersifat di permukaan, sehingga masalah anak akan tetap ada. Jika ingin ada perubahan yang cepat perlu mengintegrasikan konseling anak secara individu dengan terapi keluarga. 
Pendekatan integratif yang digunakan dalam mengatasi problematika dalam keluarga perlu ditawarkan dalam proses terapi yang komprehensif agar hasilnya positif. Jika pendekatan integratif digunakan dengan tepat dan hatihati, maka anak tidak menjadi kambing hitam atau dianggap sebagai sumber masalah. Justru sebaliknya, ketika anak mulai berubah, maka anggota keluarga lainnya akan menyadari kebutuhan mereka, mengubah pikiran, perilaku, dan keyakinannya sehingga melakukan tugas sesuai dengan perannya dalam keluarga.

Pendekatan integratif yang dapat digunakan konselor dalam proses konseling salah satunya adalah terapi keluarga eksperiensial. Konselor berpartisipasi penuh dan melibatkan diri ikut dalam kelompok untuk membentuk tenaga yang handal dalam keluarga. Tujuannya adalah agar setiap sesi konseling setiap anggota keluarga berpartisipasi aktif dan peduli terhadap apa dan bagaimana perilaku yang harus dilakukan terhadap situasi yang ada sekarang dalam keluarga. Selain itu juga sebagai media interaksi dengan komunitas secara intens di dalam maupun di luar keluarga untuk mewujudkan tujuan konseling yang hendak dicapai serta meningkatkan kesejahteraan sosial yang berdampak pada pandangan anak terhadap dunia kehidupannya di masa mendatang. Secara tidak langsung hal tersebut berpengaruh juga pada kemampuan anak dalam mengatasi permasalahan dan tantangan dalam kehidupan dalam keluarga.

Keterlibatan konselor dalam terapi keluarga eksperiensial selain menciptakan hubungan baik, juga mampu mendengarkan suara dan emosi klien serta anggota keluarga. Konselor bisa berpartisipasi penuh dalam keluarga, menjadi sahabat, orang yang dapat dipercaya dalam pertemuannya dengan anggota keluarga sehingga tercapai suasana keakraban yang alami. Keakraban dengan keluarga digunakan konselor untuk memahami dan merasakan isi hati mereka. Proses konseling yang jujur akan terjadi jika individu yang ada dalam anggota keluarga selalu berusaha untuk menempatkan diri sebagaimana adanya dan memahami orang lain sebagaimana adanya pula. ${ }^{10}$ hlm. 119.

${ }^{10}$ Willis S. Sofyan, Konseling Keluarga (Family Counseling), (Bandung: Alfabeta, 2009), 
Peran keluarga dalam membantu proses konseling anak adalah membantu konselor membuat keputusan dan memikirkan rencana tindakan untuk perubahan dan perkembangan emosi anak ke arah yang positip, menjaga kondisi kesehatan fisik dan psikis anak agar mudah melakukan komunikasi intepersonal dan intrapersonal, mampu bekerjasama dengan anggota keluarga untuk membantu proses konseling, sebagai agen pengubah lingkungan keluarga agar anak dapat mengelola emosi ke arah yang posistif.

Keluarga dalam melakukan perannya membantu konselor untuk mengelola emosi anak dapat dilakukan dengan cara yang berbeda-beda. Pengaruh budaya, keyakinan keluarga, norma, mitos, nilai, sikap akan menimbulkan persepsi anak mengenai keluarga tempat mereka hidup. Cara anak-anak berpikir dan bersikap dalam keluarga berkaitan dengan bagaimana cara anggota keluarga lain memperlakukan mereka sebagai individu maupun kelompok. Jika keluarga memahami masalah anak, dan mengenal pola interaksi yang terjadi dalam keluarga, maka akan sangat berkontribusi membantu anak dalam mengelola emosi.

Sebelum konselor melakukan proses konseling individual dengan terapi keluarga, di proses awal harus menemui seluruh anggota keluarga dan menunjukkan bahwa keluarga telah siap untuk terlibat dalam proses konseling. Keputusan yang sudah diambil harus ditaati dan dilaksanakan secara aktif oleh semua anggota keluarga. Keterlibatan keluarga dalam proses konseling memberikan kesempatan bagi anggota keluarga untuk menunjukkan perasaan emosional mereka yang berkaitan dengan proses perubahan yang terjadi dalam keluarga. Dengan menyadari perubahann yang telah terjadi diantara sesi konseling, maka perubahan selanjutnya bisa diwujudkan. Akhirnya tujuan dari konseling bisa tercapai yaitu terentaskannya masalah yang dialami oleh anggota keluarga.

Kerjasama yang dilakukan konselor, orang tua, dan anggota keluarga dalam proses konseling anak untuk mengelola emosi adalah untuk menciptakan kestabilan perkembangan emosi anak dan mampu menghindari suasana yang bisa menumbuhkan kemarahan anak. Ciptakan suasana lingkungan aman dan nyaman biar anak selalu dalam kondisi senang dan bahagia. Sebagai contoh hal-hal yang perlu diperhatikan orang tua dan 
anggota keluarga untuk membantu konselor dalam mengelola emosi anak diantaranya adalah mampu:

\section{Mengendalikan Amarah}

Kondisi orang yang sedang marah diibaratkan darah seperti mendidih, jantung berdebar, dan rasanya ingin meneriakkan apa yang dirasakan. Luapan rasa marah lebih sering terlihat pada anak kecil. Pada umumnya jika anak sedang marah disertai dengan tangisan, teriakan, bahkan bisa sampai sesak napas. Bisa juga dengan menjatuhkan diri ke lantai dan menendang. Sebagai orangtua harus mampu menaklukan amarah anak, misalnya dengan menggenggam tangannya dan meminta anak untuk menarik napas panjang. Setelah ia tenang ajak anak untuk mengungkapkan perasaannya lewat kalimat yang sederhana. Hindari merespons kemarahan anak dengan teriakan dan omelan karena bisa menambah anak frustasi.

\section{Melawan Rasa Takut}

Rasa takut yang dialami anak-anak adalah hal yang wajar, misalnya takut akan kegelapan, binatang tertentu, orang asing, atau monster. Orangtua tidak perlu bersikap overprotective bila anak merasa takut. Namun demikian hindari sikap meremehkan. Cari tahu apa penyebab ketakutan yang dialami anak. Setelah diketahui singkirkan jauh-jauh ketakutan yang dialami anak dengan menceritakan kenyataan yang sesungguhnya. Misalnya takut pada kucing, katakan bahwa kucing itu tidak akan menggigit jika tidak disakiti atau diganggu. Begitu juga takut akan kegelapan. Jelaskan bahwa kegelapan tidak akan menyakiti anak, kemudian ajak anak sedikit demi sedikit bisa merasakan kegelapan. Tentu saja orangtua harus mendampingi anak untuk melatih agar tidak takut pada kegelapan. Jika anak gemetar peluklah. Yang jelas orang tua harus mengajarkan kepada anak untuk mengenali dan mengatasi penyebab ketakutan yang muncul pada diri anak.

\section{Membuang Cemburu}

Anak sering merasa cemburu dengan teman yang memiliki mainan bagus, suara merdu, orangtua yang baik dan dia sendiri belum tahu mengapa 
dia ingin memilikinya tapi tidak bisa terpenuhi. Sebagai orangtua harus mampu membesarkan hatinya dan menjelaskan bahwa setiap individu memiliki kelebihan dan kelemahan masing-masing. Mengungkapkan kebanggaan kepada anak terhadap apa yang dia miliki. Berikan penjelasan sederhana yang mudah dicerna anak-anak.

\section{Meredakan Kesedihan}

Rasa sedih dan kecewa bisa membuat si kecil murung dan sedih, untuk itu biarkan anak mengekspresikan perasaannya. Orang tua tidak perlu banyak bicara, dan harus bisa menghindari kata-kata yang menyudutkan anak, misalnya: "Begitu saja kok sedih!" Hal lain orang tua bisa menghibur anak dengan membeli makanan kesukaan, sambil memotivasi anak agar mau bercerita tentang masalah yang membuat dia sedih. Kuncinya adalah orangtua melatih anak untuk mampu menceritakan atau berani mengungkapkan perasaannya biar anak menjadi terbuka.

\section{G. Kesimpulan}

Masing-masing anggota keluarga termasuk didalamnya anak-anak akan berpikir dan berperilaku sesuai dengan perannya untuk memenuhi kebutuhan emosionalnya. Untuk melaksanakan tugas sesuai dengan perannya dalam keluarga tidaklah mudah, jika tidak tercipta komunikasi yang sehat dan efektif. Masing-masing pikiran, perilaku, dan persepsi dalam keluarga dipengaruhi oleh perilaku anggota keluarga lainnya dan perubahan perkembangan dalam keluarga serta kejadian-kejadian eksternal. Kadang cara yang digunakan anak untuk memenuhi kebutuhan emosionalnya tidak sesuai dan akan menghasilkan masalah bagi mereka dan anggota keluarga lainnya. Meskipun demikian, anak berpikir dan berperilaku berdasarkan cara pandang yang terbaik menurut yang mereka ketahui.

Sikap orang tua dalam merespon perilaku dan sikap anak juga berbeda dengan kemauan anak, sehingga memunculkan masalah pada anak. Hal itu merupakan tantangan bagi keluarga bagaimana menghadapi dan mengelola perkembangan emosional yang terjadi dalam anggota keluarga. Bagi anakanak, banyak hal yang terjadi dalam keluarga di luar kontrol mereka, seperti 
misalnya; adanya perang, tertimpa musibah, bencana, pindah rumah, sekolah, dan perceraian keluarga. Hal tersebut akan mempengaruhi dan berdampak pada persepsi, pikiran, cara pandang, dan perilaku anak-anak dalam keluarga.

Berbagai macam problematika keluarga ada beberapa masalah yang mudah bisa diatasi adapula yang membutuhkan bantuan orang lain untuk menyelesaikan problematika dalam keluarga melalui proses konseling. Melaksanakan proses konseling anak berbeda dengan remaja dan orang dewasa. Konselor harus memahami dunia anak serta mampu berkomunikasi secara verbal maupun non verbal pada anak. Bekerjasama dengan anggota keluarga agar melaksanakan perannya dalam proses konseling anak, sehingga proses pencapaian tujuan dalam proses konseling bisa fokus dan maksimal.

Melaksanakan konseling anak tidak mudah, untuk itu dibutuhkan pendekatan yang tepat dan integratif, salah satunya adalah menggunakan terapi keluarga eksperiensial. Pendekatan ini menekankan pada pentingnya pengalaman dan mengekspresikan emosi here and now dan proses pertumbuhan alamiah dalam keluarga, meningkatkan rasa memiliki keluarga, dan meningkatkan kemampuan keluarga untuk memberikan kebebasan sebagai individu setiap anggotanya.

Peran terapi keluarga eksperiensial adalah sebagai katalisator perubahan, dengan memanfaatkan dampak personal individu dalam keluarga. Membantu konselor membuat keputusan dan memikirkan rencana tindakan untuk perubahan dan perkembangan emosi anak ke arah yang positip, menjaga kondisi kesehatan fisik dan psikis anak agar mudah melakukan komunikasi intepersonal dan intrapersonal, mampu bekerjasama dengan anggota keluarga untuk membantu proses konseling, sebagai agen pengubah lingkungan keluarga agar anak dapat mengelola perkembangan emosi ke arah yang posistif.] 


\section{Daftar Pustaka}

Geldard Kathryn dan G David, Konseling Keluarga, Yogyakarta: Pustaka Pelajar, 2011. , Konseling Anak-anak, Yogyakarta: Pustaka Pelajar, 2011.

Gunarsa, D Singgih, Psikologi Anak Bermasalah, Jakarta: Gunung Mulia, 2009.

Hurlock B, Elizabeth, Psikologi Perkembangan Suatu Pendekatan Sepanjang Rentang Kehidupan, Jakarta: Erlangga, 2004.

Kertamuda E, Fatchiah, Konseling Pernikahan Untuk Keluarga Indonesia, Jakarta: Salemba Humanika, 2009.

Rumini S dan Sundari S., Perkembangan Anak dan Remaja, Jakarta: Rineka Cipta, 2004.

Surya, Muhamad, Psikologi Konseling, Jakarta: Pustaka bani Quraisy, 2003.

Walgito, Bimo, Pengantar Psikologi Umum, Yogyakarta: Andi Offset, 2004.

Willis S, Sofyan, Konseling Keluarga, Bandung: Alfabeta, 2009. 